\title{
Bio-SiC ceramics coated with hydroxyapatite using gas-detonation deposition: An alternative to titanium-based medical implants
}

\author{
M.I.Klyui, V.P.Temchenko, O.P.Gryshkov, \\ V.A.Dubok ${ }^{*}$, V.P.Kladko, A.V.Kuchuk, V.M.Dzhagan, \\ V.O.Yukhymchuk, V.S.Kiselov
}

\begin{abstract}
V.Lashkaryov Institute of Semiconductor Physics, National Academy of Sciences of Ukraine, 41 Nauky Ave., 03028 Kyiv, Ukraine

*I.Frantsevich Institute for Problems of Material Science, National Academy of Sciences of Ukraine, 3 Krzhyzhanivskogo Str., 03680 Kyiv, Ukraine
\end{abstract}

\section{Received November 27, 2012}

\begin{abstract}
Silicon-carbide ( $\mathrm{SiC}$ ) ceramics synthesized using forced infiltration and coated with bioactive hydroxyapatite (HA), represents a great potential for replacement of traditional titanium medical implants. In this paper the surface morphology, structural properties and phase content of HA coatings deposited onto nano-porous bio-SiC ceramics with pore orientation being parallel or perpendicular to the plain of subsequently deposited HA film have been studied. The HA coatings produced at $5 \mathrm{~s}$ of deposition contained cracks, while the uniform hydroxyapatite coating has been produced at $10 \mathrm{~s}$ of deposition. X-ray diffraction analysis revealed that the HA coatings preserve crystal structure of the initial hydroxyapatite powder during deposition. From the intensity ratio of Raman scattering peaks, corresponding to crystalline $\left(967 \mathrm{~cm}^{-1}\right)$ and amorphous $\left(951 \mathrm{~cm}^{-1}\right) \mathrm{HA}$, the least and most crystalline structures were found. The structural perfection of the HA coating was higher for SiC substrates with parallel pore orientation (with respect to the plane of HA growth), indicating that structural properties of SiC ceramics affect the morphological and structural perfection of deposited HA coating.
\end{abstract}

Карбид-кремниевая ( $\mathrm{SiC})$ керамика с осажденным биоактивным покрытием на основе гидроксиапатита (ГАП) имеет потенциал по замене традиционных титановых медицинских имплантов. В работе методами рентгеноструктурного анализа, комбинационного рассеивания света и оптической микроскопии исследованы морфология, структурные свойства и фазовый состав покрытий ГАП, осажденных на нанопористую био-SiC керамику с параллельной или перпендикулярной ориентацией пор газо-детонационным методом. После 5 секунд осаждения на покрытии проявлялись микротрещины и отслоения, в то время как равномерное покрытие образовалось вследствие 10 секунд осаждения. Рентгеноструктурный анализ покрытия выявил сохранение кристаллической структуры исходного порошка. Результаты комбинационного рассеивания света обнаружили увеличение отношения площади кристаллического пика (967 cм $\left.{ }^{-1}\right)$ относительно аморфной составляющей $\left(951 \mathrm{~cm}^{-1}\right)$. Данное отношение оказалось наибольшим для покрытий, осажденных на $\mathrm{SiC}$ керамику с параллельной ориентацией пор, указывая на то, что структурные свойства SiC керамики влияют на морфологию и структурное совершенство осажденных покрытий ГАП. 


\section{Introduction}

The necessity of replacement of damaged bones as a result of accidents, bone senescence etc. is significantly increasing nowadays. When the replacement of bones is caused by bone senescence, traditional lifetime of artificial medical implants achieved until now, seems to be long enough (20 years). However, even in this case real medical implants are far from the required lifetime. Medical implants for bone replacement are commonly made of titanium alloys (Ti-6Al-4V) and coated with hydroxyapatite (HA). It is not the bio-degradation of HA that seems to decrease the required lifetime, but the deposition process that has been used to obtain HA coating. The detaching of HA layers may result from the formation of amorphous phase at the coating-titanium boundary during deposition. This significantly decreases the adhesion of the coating to the substrate.The detachment of the HA coating provokes a great decrease in mechanical stability of the whole implant and thus requires an immediate surgical intervention.

Bioactive medical coatings traditionally made of $\mathrm{HA}\left(\mathrm{Ca}_{10}\left(\mathrm{PO}_{4}\right)_{6}(\mathrm{OH})_{2}\right)$ are now widely used in reconstructive surgery and orthopedics for replacement of damaged bone tissue. HA possesses high bio-compatibility with human body, forms direct chemical bonds with bone tissue and can be gradually replaced by newly-formed living bone. Crystallinity of the coating, crystalline phase composition, adhesion of HA coating to the substrate affect the life time of the medical implant. Structural properties of HA coatings depend mainly on method used for HA powder deposition.

There are only a few methods to be used for deposition of HA onto titanium-based medical implants: plasma spraying [1], high-velocity oxy-fuel deposition [2] and pulsed laser deposition [3]. However, only the first one is the most profitable and is thus frequently used for deposition. Despite of this, HA coatings deposited by plasma spraying do not have sufficient adhesion to titanium implant. Moreover, this method is not able to obtain thick enough HA coating for long-term performance. In plasma spraying, a flux of fused HA particles, having temperature above $1500{ }^{\circ} \mathrm{C}$, strikes a much colder (about $800{ }^{\circ} \mathrm{C}$ ) metal substrate. The rapid cooling (quenching) causes an essential disorder of crystal structure of HA and formation of amorphous HA phase at the coating-substrate interface. On the one hand, this phenomenon improves the mechanical properties of the coatings, especially its adhesion [4,5]. On the other hand, fast resorption of the amorphous phase was observed in-vivo and in-vitro [6]. To reduce the mechanical stress, thickness of the coating should be below $50 \mu \mathrm{m}$. However, coatings of such thickness get dissolved much faster than the required lifetime. The similar phenomena are inherent to all high-temperature deposition methods. Besides, the majority of deposition methods have a number of other significant disadvantages: insufficient adhesion, high porosity, imperfection of crystal structure, disorder of chemical and phase structure of coatings as well as their small thickness due to the low productivity of the process.

In order to obtain high-quality bioactive HA-based medical implants, the deposition techniques should provide HA powder and substrate with low heating during deposition, high adhesion, low porosity of the coating and the lowest contamination level, preservation of chemical and phase composition of HA, high productivity of the process and reasonable thickness of the coating. Such conditions could be realized when the adhesion of the coating is provided by high kinetic energy of the HA particles bombarding the substrate, as it occurs under gas detonation deposition. Powder acceleration and its further deposition onto substrate are achieved using the energy of gaseous mixtures explosion. As it was recently shown [7], bio-SiC ceramics produced by forced infiltration can be coated with HA by gas-detonation deposition. However, despite of increased process temperature, the deposition process may cause significant changes in crystal structure and phase composition of the initial HA powder.

Bio-SiC ceramics seems to have a great potential to be used as a material for biomedical implant engineering when combining its mechanical properties and porous structure with bioactivity of HA coatings. The SiC ceramics can be synthesized by Chemical Vapor Infiltration (CVI), Liquid Silicon Infiltration (LSI) and Spark Plasma Sintering techniques (SPS) [8-10]. The Forced infiltration with liquid silicon of carbon matrices derived from different hardwood precursors is able to produce SiC porous ceramics that seems to reproduce the porous structure of bone [11]. The porosity of SiC ceramics ranging from 4 up to $100 \mu \mathrm{m}$ can be controlled by the parameters of the technological process. Furthermore, the ad- 
vantages of bio-SiC ceramics make it promising for engineering of light, robust and cheap medical implants.

In this paper, bio-SiC porous ceramics synthesized from different wood precursors with pore orientation being parallel or perpendicular to the plain of the subsequently deposited HA-film was coated with HA by gas-detonation deposition. The effect of pore orientation on surface morphology of HA coating as well as the effect of gas-detonation process on the structural properties and phase content of HA coating were studied and discussed.

\section{Experimental}

\subsection{Synthesis of bio-SiC ceramics}

Biomorphic nano-porous SiC ceramics was synthesized using forced infiltration with liquid silicon of carbon matrices derived from different hardwood precursors (Cherry tree (Prunus avium), Hornbeam (Carpinus) and Sapelli (Entandrophragma cylindricum)). This process involves several steps in preparation of SiC ceramics: impregnation of carbon matrices by silicon and synthesis of SiC ceramics (Fig. 1a) [12]. Briefly, at the first stage the carbon templates from indicated above wood specimens are prepared. The wood specimens were previously dried at $90^{\circ} \mathrm{C}$ for $15 \mathrm{~h}$. The technology of wood pyrolysis in a flow of inert argon or nitrogen gas at $900^{\circ} \mathrm{C}$ is utilized for these purposes. The second stage is forced infiltration of the carbon matrices. The goal of this stage is an evaporation of silicon excess. This stage was fulfilled in vacuum, slowly increasing the temperature at a rate of $10-20^{\circ} \mathrm{C} / \mathrm{min}$ up to $T_{\max }=$ $1600-1900^{\circ} \mathrm{C}$. The duration of the second stage was $2 \mathrm{~h}$. Finally, if required, the excess carbon is burn out from the final products in the furnace in oxygen atmosphere at $900^{\circ} \mathrm{C}$ for $2 \mathrm{~h}$. Synthesized in this way $\mathrm{SiC}$ ceramics samples were used as substrates for HA powder deposition.

\subsection{HA powder preparation}

HA powder was synthesized by precipitation from a solution of calcium nitrate and ammonium hydrogen phosphate accordingly to the following chemical reaction:

$$
\begin{aligned}
& \mathrm{CaNO}_{3}+6\left(\mathrm{NH}_{4}\right)_{2} \mathrm{H}\left(\mathrm{PO}_{4}\right)+8\left(\mathrm{NH}_{4}\right) \mathrm{OH}=(1) \\
= & \mathrm{Ca}_{10}\left(\mathrm{PO}_{4}\right)_{6}(\mathrm{OH})_{2}+20\left(\mathrm{NH}_{4}\right) \mathrm{NO}_{3}+3 \mathrm{H}_{2} \mathrm{O} .
\end{aligned}
$$

The precipitation was carried out at room temperature and $\mathrm{pH}=12$ when stir-

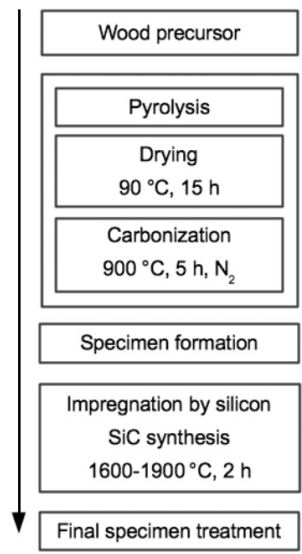

a)

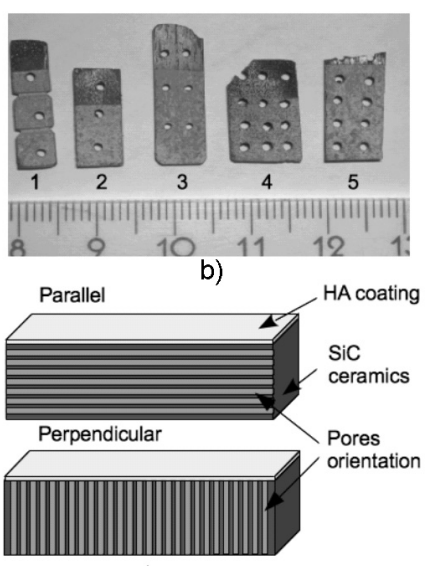

c)
Fig. 1. Synthesis of porous SiC ceramics (a), samples of SiC ceramics with deposited HA coatings (b) and orientation of pores in SiC ceramics with respect to deposited HA coating (c).

ring gently. The precipitate was left for 1 day in the parent solution. The solution was periodically stirred, boiled for $1 \mathrm{~h}$, cooled, precipitated, filtered, added to distilled water and again precipitated. After five-fold repetition, the precipitate was washed with hot distilled water. Afterward, the obtained powder was dried at $120^{\circ} \mathrm{C}$ and annealed in air at $1000^{\circ} \mathrm{C}$ for $1 \mathrm{~h}$. Then the precipitate was transformed into the uniform conglomerate, which had a porosity of $30 \%$ and strength of 5-7 MPa. Preliminary X-ray analysis revealed pure crystalline HA with surface area $1 \mathrm{~m}^{2} / \mathrm{g}$ (measured by Brunauer-Emmett-Teller method), that corresponds to the initial size of powder particles $(2 \mu \mathrm{m})$. The other phases (tetra calcium phosphate, amorphous calcium phosphate etc.) were absent. Accordingly to the previous studies [13], the powder with 63-75 $\mu \mathrm{m}$ fractions has to be used for gas detonation deposition. Such powder was prepared by grinding with further sieving by use of appropriate sieves.

\subsection{Deposition of $\mathrm{HA}$ powder}

Gas-detonation deposition equipment (PERUN-S, Patents [14-16]) was used to deposit HA powder onto SiC ceramic substrates. The process parameters (distance between detonation gun and SiC substrate, powder feeding rate etc.) have been previously optimized as described earlier [17] and then used to control the deposition process. Prior to deposition, HA powder (fraction 63-75 $\mu \mathrm{m}$ ) was annealed during 
Table 1. Parameters of the samples studied

\begin{tabular}{|c|c|c|c|c|c|}
\hline Sample & Material & Wood precursor & $\begin{array}{c}\text { Pore } \\
\text { orientation }\end{array}$ & $\begin{array}{l}\text { Fraction of HA } \\
\text { powder, } \mu \mathrm{m}\end{array}$ & Deposition time, $\mathrm{s}$ \\
\hline 1 & \multirow{5}{*}{$\begin{array}{c}\mathrm{SiC} \\
\text { ceramics }\end{array}$} & Cherry tree (Prunus avium) & \multirow{5}{*}{$\begin{array}{c}\text { parallel } \\
\text { perpendicular } \\
\text { parallel } \\
\text { perpendicular }\end{array}$} & \multirow[t]{5}{*}{$63-75$} & \multirow[t]{5}{*}{$5 / 10$} \\
\hline 2 & & Cherry tree (Prunus avium) & & & \\
\hline 3 & & Hornbeam (Carpinus) & & & \\
\hline 4 & & $\begin{array}{c}\text { Sapelli (Entandrophragma } \\
\text { cylindricum) }\end{array}$ & & & \\
\hline 5 & & $\begin{array}{c}\text { Sapelli (Entandrophragma } \\
\text { cylindricum) }\end{array}$ & & & \\
\hline
\end{tabular}

$30 \mathrm{~min}$ at $180^{\circ} \mathrm{C}$. After annealing, HA powder was transported to the special feeders and used for deposition. Gas-detonation deposition process is cyclic (up to 9 cycles/s) and uses high-kinetic energy of explosive gases (oxygen - propan/butan) in order to transport loaded HA powder to the substrate at high velocities (up to $1200 \mathrm{~m} / \mathrm{s}$ ). Briefly, the deposition includes several steps: feeding of explosive mixture into the barrel, feeding of HA powder, end of mixture feeding and expulsion with neutral gas, explosion of mixture and exhaustion of detonation products, expulsion of the barrel with neutral gas [see also 17]. The process cyclicity was adjusted to $6 \mathrm{cy}-$ cles $/ \mathrm{s}$ and remained constant. In order to investigate the effect of deposition process on the structure of resulted HA coating, two experimental sets with 5 samples in each were obtained after 5 and $10 \mathrm{~s}$ of deposition respectively (Fig. 1b). HA powder deposition has been performed onto SiC ceramics with parallel or perpendicular pore orientation with respect to the plain of the HA-film (except for the sample 3 - Hornbeam (Carpinus) - only sample with parallel orientation has been studied) (Fig. 1b, c, Table 1).

\subsection{Structural and phase content characterization}

Surface morphology of the coating was observed under optical microscope (Shimadzu, Japan) using $100 \times$ and $500 \times$ magnification. X-ray diffraction analysis (XRD) was used to study the crystal structure of the initial powder and the HA coatings onto SiC ceramics derived from different wood precursors with parallel or perpendicular pore orientation. X-ray spectra were collected using high-resolution PANalytical X'Pert Pro MRD diffractometer (The Netherlands) with standard coplanar sketch and sliding geometry tool kits. The phase com- position and crystal structure perfection were studied by Raman spectroscopy (RS). Raman spectra of the initial HA powder and deposited coatings were collected at room temperature using DFS-24 double monochromator and photon counting system for the registration. The continuous radiation with power of $\sim 50 \mathrm{~mW}$ and wavelength of $532 \mathrm{~nm}$ of the diode-pumped solid-state laser or $514.5 \mathrm{~nm}$ of an argon ion laser were used for an excitation.

The results of $\mathrm{RS}$ and X-ray diffraction for HA coatings obtained after $5 \mathrm{~s}$ of deposition did not contain any sufficient information to explain the effect of deposition process on the structure of the HA coatings and thus are not shown in section results and discussion.

\section{Results and discussion}

\subsection{Optical microscopy}

Images of $\mathrm{SiC}$ ceramics with $\mathrm{HA}$ coating have been collected using $100 \times$ and $500 \times$ magnification. Fig. 2 represents the surface morphology of HA coating obtained after 5 and $10 \mathrm{~s}$ of deposition for both perpendicular and parallel pore orientation. As can be seen from Fig. 2, the HA coating obtained after $5 \mathrm{~s}$ of deposition has irregular structure containing areas with thinner layer of the HA coating (Fig. 2, 1B-5B). These areas might be situated on the surface irregularities of initial SiC ceramics. Moreover, some cavities with different depth are observed in the sample with perpendicular pore orientation. They are especially decorated after $5 \mathrm{~s}$ of deposition of thing $\mathrm{HA}$ coating (Fig. 2, 2B, 4B). However, when the HA coating was obtained after $10 \mathrm{~s}$ of deposition (Fig. 2, 1C-5C), these cavities were almost absent and the uniform coating was formed. The irregular morphology of HA coating for some samples obtained after $5 \mathrm{~s}$ of deposition may be due to the insufficient or excessive powder feeding rate during 


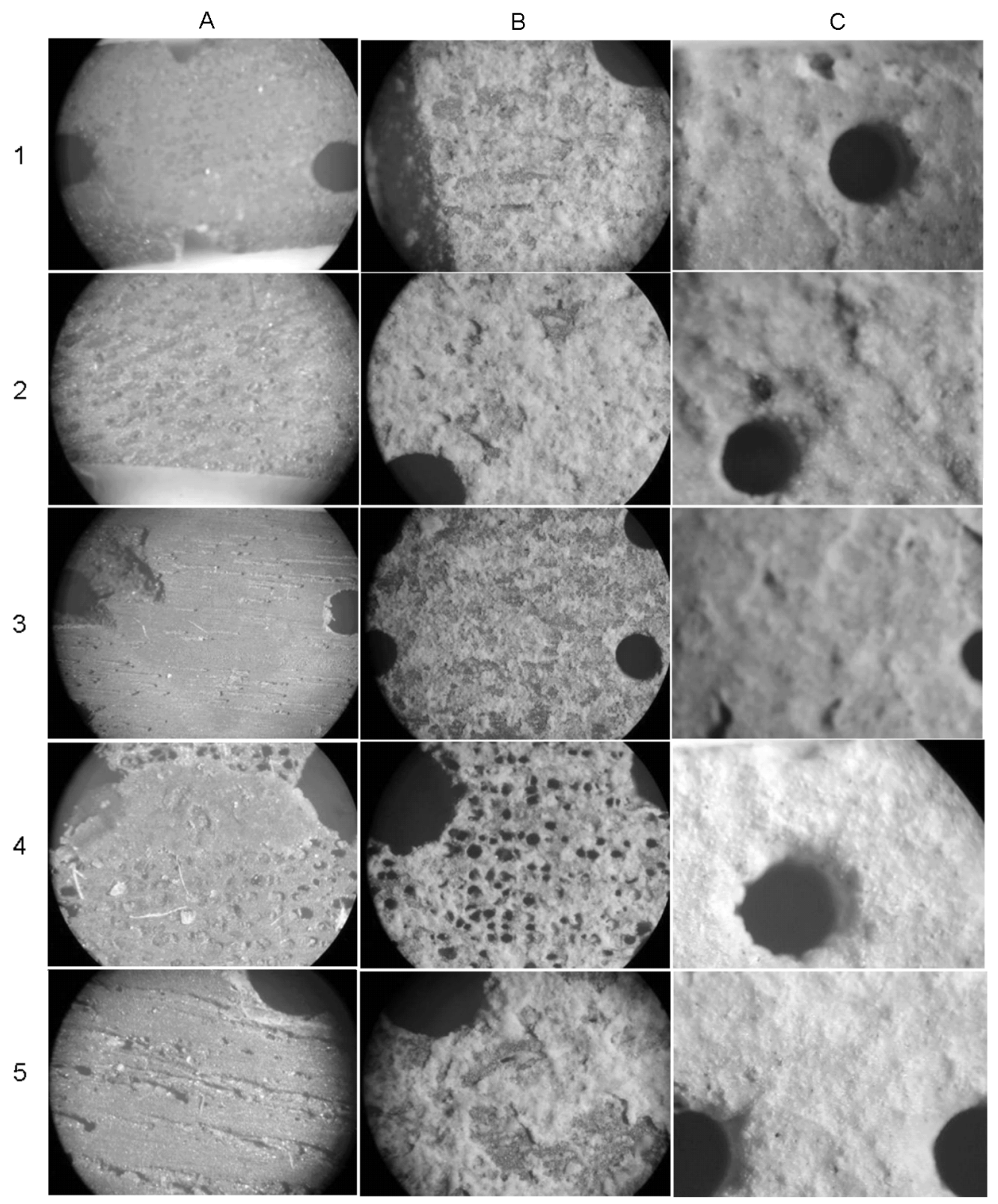

Fig. 2. Morphology of HA coatings on SiC ceramics with different pore orientation. A - Noncoated SiC ceramics (magnification 100 $\times$ ); B - HA coating (deposition time: 5 s; magnification: 100 $\times$ ); C - HA coating (deposition time: $10 \mathrm{~s}$; magnification: 500×).

deposition. In time of deposition the first layers of HA coatings were possibly formed under an interaction of high-speed flow of HA particles extremely heated to $1000^{\circ} \mathrm{C}$ by the products of detonation with more colder $\mathrm{SiC}$ substrate. This interaction might cause flaking of the coating from substrate. From the other hand, the flaking could be observed owing to the formation of transition amorphous layer between SiC substrate and HA coating. This assumption may be further approved by RS and XRD analysis. For the next layers of $\mathrm{HA}$ it was easier to be deposited onto preliminary obtained HA coatings. The coatings obtained after $10 \mathrm{~s}$ of deposition did not contain any irregularities in its structure and were uniform over the surface.

\subsection{X-ray diffraction}

X-ray diffraction patterns of the synthesized HA are shown in Fig. 3. All data were collected over $2 \theta$ of $25^{\circ}$ to $70^{\circ}$ range with a step of $2^{\circ}$. Comparison of the peaks presented in the initial HA powder with the 


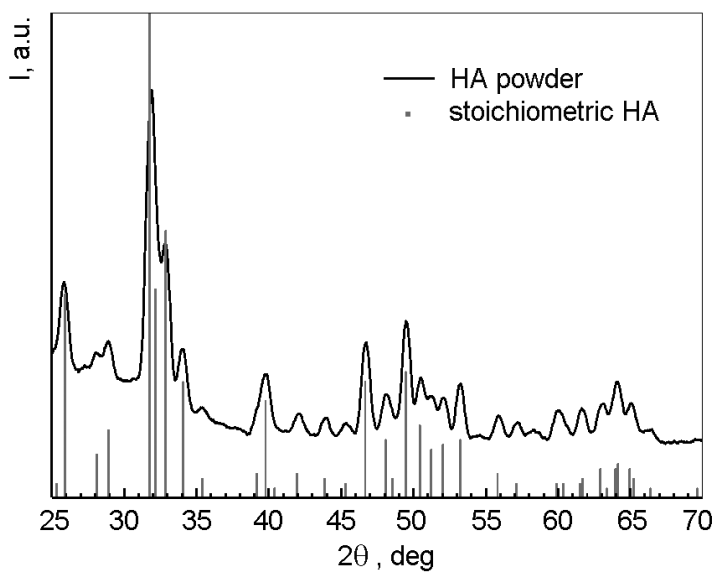

Fig. 3. XRD patterns of the initial HA powder (black line) and the stoichiometric hydroxyapatite according to JCPDS 00-0090432 (gray vertical lines).

diffraction standards (Fig. 3, gray vertical lines) revealed an absence of other phases.

Fig. 4 represents XRD patterns of the obtained HA coatings onto $\mathrm{SiC}$ ceramics with different pore orientation for samples 1-5 (Fig. 4, 2-1-2-5) numbered accordingly to Table 1. Pattern for the initial HA pow$\operatorname{der}$ (Fig. 4, 1) is also shown. Intensive peak at $2 \theta=44.5^{\circ}$ corresponds to the sample holder made of Fe. As can be seen from Fig. 4 , distinct peaks for $\operatorname{SiC}\left(2 \theta=35.6^{\circ}, 41.4^{\circ}\right)$ are observed. This indicates very thing layer and inhomogeneity of the deposited HA coating. However, analysis of the patterns found that the intensity of these peaks varies between the samples due to the difference in thickness for each deposited HA coating. It should be noted that HA peaks are broadened as compared to the initial HA powder indicating some disordering in the structure of the coating. This could be explained by the influence of increased process temperature. Meanwhile, sample 5 has less intensive SiC peaks as compared to other samples and thus thicker HA coating. The results of XRD are in a good correlation with the optical microscopy, where sample 5 showed the improved surface morphology (Fig. 2, 5C). Some unknown peak was observed at $2 \theta=47.4^{\circ}$. Interestingly, that it has higher intensity compared to more intensive $\mathrm{HA}$ peaks at the region $2 \theta=$ $31^{\circ}-34.4^{\circ}$ and appeared more intensive for sample 4 . The reason of an appearance of this peak is, however, unclear. Search through X-ray spectra database found that the appearance of this peak could be attrib-

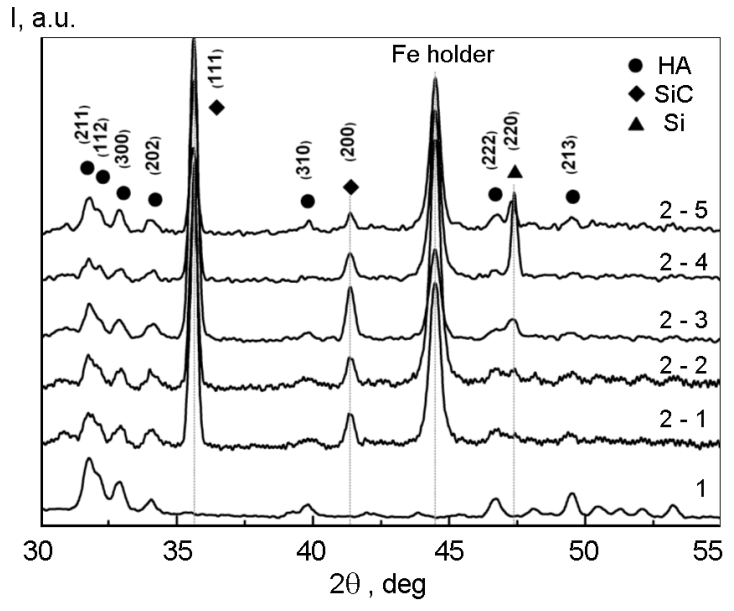

Fig. 4. XRD patterns of the initial HA powder (1) and HA coatings on SiC ceramics with different pore orientation (2-1-2-5).

uted to the presence of Si (220). Taking into account that the broadening of peaks at the HA region for sample 5 is the lowest, the correlation between structure perfection of the substrate and structure perfection of the coating takes place. The Miller indices $(h k l)$ for HA (space group $P 6_{3 / m}$ ), SiC and Si are inscribed over the diffraction lines of samples 2-5 (Fig. 4).

\subsection{Raman scattering}

Raman spectroscopy is traditionally used to determine inter-atomic bonds, structural defects and impurities, etc. Calcium phosphates can be completely characterized by vibration spectroscopic properties of $\mathrm{PO}_{4}{ }^{3-}$ group. This molecular formation provides Raman spectra with four dominant vibrations of $\mathrm{P}-\mathrm{O}$ bonds $\left(v_{1} \approx 960 \mathrm{~cm}^{-1}\right.$, $v_{2} \approx 435 \mathrm{~cm}^{-1}, v_{3} \approx 1050 \mathrm{~cm}^{-1}, v_{4} \approx 590 \mathrm{~cm}^{-1}$ ). The structural properties and phase composition have been studied in terms of comparing the results for the initial powder and obtained coatings. The most intensive band $\left(v_{1} \approx 960 \mathrm{~cm}^{-1}\right)$ was chosen for analysis, since this band has been previously observed for both single-crystal and poly-crystalline thin film of HA samples [18-20]. The intensity, frequency and line-width of this band were used to analyze the influence of deposition process on the properties of the HA coatings obtained onto SiC ceramics. The Raman peaks for the samples with the coating obtained after $5 \mathrm{~s}$ of deposition was not strong enough for analyzing (Fig. 5a, insert). Therefore, the analysis of Raman scattering was based on the spectra measured for the coatings obtained as a result of 10 s deposition. 


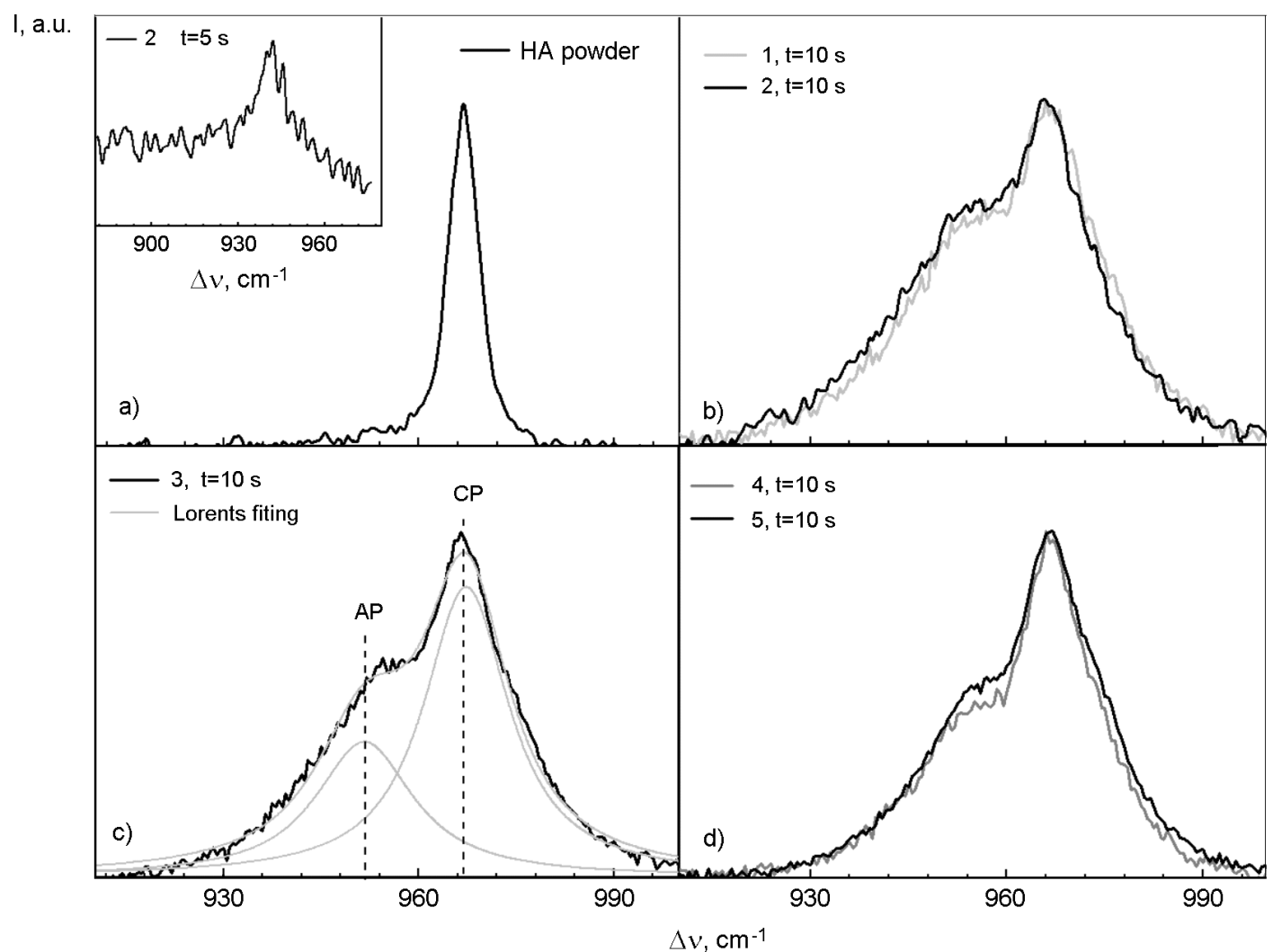

Fig. 5. Raman spectra of the initial HA powder (a) and HA coating obtained as a result of $10 \mathrm{~s}$ deposition $(\mathrm{b}-\mathrm{c})$. Insert to (a) shows week signal for HA coating after $5 \mathrm{~s}$ of deposition. A representative fit with two components corresponding to the crystalline (CP) and amorphous (AP) phases is shown in (c).

Raman spectra of the HA coatings and the initial HA powder are presented in Fig. 5. As it was supposed, the strong band at $967 \mathrm{~cm}^{-1}$ that corresponds to the crystalline phase of the initial HA powder (Fig. 5a) was observed. This figure also shows the fitting of experimental spectra with Lorentz profiles peaked approximately at $v_{1} \approx 967 \mathrm{~cm}^{-1}$ and $v_{2} \approx 952 \mathrm{~cm}^{-1}$. No high-frequency band was determined. However, it was observed for plasma sprayed HA coating on titanium substrates [21]. Despite of this, considerable broadening of the main vibration band $\left(v_{1} \approx 967 \mathrm{~cm}^{-1}, \quad \Delta v=13.5-15.5 \mathrm{~cm}^{-1}\right) \quad$ as compared to the initial HA powder $(\Delta v=$ $7.7 \mathrm{~cm}^{-1}$ ) and an appearance of additional low-frequency profile were determined. This broadening might result from the crystal phase disordering or high concentration of impurities in the coating. The low-frequency component $\left(v_{2} \approx 952 \mathrm{~cm}^{-1}\right)$ can be related to amorphous phase of the HA coating, as it has been also suggested in $[22,23]$. Although, the presence of other phases of calcium phosphate, such as di-, tri-, tetra-calcium phosphates $\quad\left(\mathrm{CaHPO}_{4} \quad(\mathrm{Ca} / \mathrm{P}=1), \quad \mathrm{Ca}_{3}\left(\mathrm{PO}_{4}\right)_{2}\right.$

Table 2. Results of Lorentz peak fitting of RS spectra of the HA coating and initial powder and structural perfection calculated accordingly to the equation (2).

\begin{tabular}{|c|c|c|c|c|c|c|c|c|c|c|c|}
\hline \multirow{2}{*}{$\begin{array}{c}\text { Parameters of } \\
\text { the Raman peak }\end{array}$} & \multirow{2}{*}{$\begin{array}{c}\text { HA } \\
\text { powder }\end{array}$} & \multicolumn{2}{|c|}{1} & \multicolumn{2}{|c|}{2} & \multicolumn{2}{|c|}{3} & \multicolumn{2}{|c|}{4} & \multicolumn{2}{|c|}{5} \\
\hline & & $\mathrm{CP}$ & AP & $\mathrm{CP}$ & AP & $\mathrm{CP}$ & $\mathrm{AP}$ & $\mathrm{CP}$ & $\mathrm{AP}$ & $\mathrm{CP}$ & $\mathrm{AP}$ \\
\hline Area & 7.70 & 20.62 & 13.32 & 18.46 & 16.58 & 20.82 & 11.16 & 19.06 & 7.32 & 22.04 & 7.25 \\
\hline Frequency, $\mathrm{cm}^{-1}$ & 966.82 & 967.31 & 951.64 & 966.74 & 951.32 & $967 ., 31$ & 951.66 & 967.22 & 951.92 & 967.35 & 952.37 \\
\hline Width, $\mathrm{cm}^{-1}$ & 4.83 & 15.55 & 18.60 & 14.49 & 20.78 & 15.50 & 17.88 & 13.48 & 14.70 & 15.35 & 14.43 \\
\hline $\begin{array}{l}\text { Structural } \\
\text { perfection }\end{array}$ & & \multicolumn{2}{|c|}{1.55} & \multicolumn{2}{|c|}{1.11} & \multicolumn{2}{|c|}{1.87} & \multicolumn{2}{|c|}{2.60} & \multicolumn{2}{|c|}{3.04} \\
\hline
\end{tabular}


$(\mathrm{Ca} / \mathrm{P}=1.5)$ and $\mathrm{Ca}_{4}\left(\mathrm{PO}_{4}\right)_{2} \mathrm{O}(\mathrm{Ca} / \mathrm{P}=2)$ respectively) might also cause an appearance of the low-frequency band. According to [23], the contribution of the latter compound to the low-frequency spectrum component cannot be excluded. On the other hand, the presence of di-calcium phosphate is not likely, because for this compound the vibration frequency $v_{1}$ of $\mathrm{P}-\mathrm{O}$ bonds should be higher by $20 \mathrm{~cm}-1$ as compared to stoichiometric HA [24].

In order to study the effect of the type of initial wood specimen and pore orientation on structure of the HA coating, the intensity, peak area and line-width have been analyzed. Table 2 represents the results of Lorentz fitting as well as analysis of the peak parameters for the samples numbered in correspondence with Fig. 1b and Table 1. Here, CP and AP are the values for the crystalline and "amorphous" bands, respectively. According to these results, frequency and width of these peaks did not vary significantly indicating an absence of oxyapatite, observed at $v \approx 970 \mathrm{~cm}^{-1}$ for HA powder deposited onto titanium substrate (see also [13]). The structural perfection of the HA coating was estimated as the ratio of peak area for CP and AP bands as follows:

$$
\text { Structural perfection }=C P / A P \text {. }
$$

The highest ratio of structural perfection $(3,04)$ was observed for the sample, derived from Sapelli (Entandrophragma cylindricum) wood specimen with parallel pore orientation. The lowest ones were found for the samples with perpendicular pore orientation, i.e. 1,11 and 2,60 for the samples, synthesized from Cherry tree (Prunus avium) and Sapelli (Entandrophragma cylindricum), respectively. Thus, the structural properties of the HA coatings strongly depend on the structure and pore orientation of SiC ceramics as well as on wood-type, being used for the sample preparation.

Another parameter is the width of Raman peak. It can be used as a measure of structural quality of the coatings: the larger width corresponds to less perfect structure. As can be seen from Table 1, variation of the Raman peak width between the samples does not correspond to variation of the degree of perfection determined from the intensity ratio of $\mathrm{AP}$ and $\mathrm{CP}$ components. Probably, the Raman peak width is affected predominantly by the imperfections inside the crystalline HA layer. At the same time, the intensity of the AP Raman peak is mainly due to the amorphous layer adjacent to the crystalline HA layer itself.

\section{Conclusions}

Herein, we indicate the possibility to use HA coated SiC ceramics produced by gasdetonation deposition as promising ceramic material for medical implant engineering. Our investigation of surface morphology of the coating has proved that using gas-detonation deposition the uniform and crystalline HA coatings onto bio-SiC porous ceramics can be produced after as few as $10 \mathrm{~s}$ of deposition that is not possible to perform by other traditionally used deposition techniques. X-ray diffraction analysis and Raman scattering studies revealed dependence between morphology and structure properties of the coatings and SiC ceramics. Raman scattering also revealed an appearance of the new band related to nucleation of the "amorphous" phase $\left(952 \mathrm{~cm}^{-1}\right)$. It was shown that SiC ceramics with parallel pore orientation is preferred for perfect HA coating. The results of these studies may be attractive for designing of HA-based $\mathrm{SiC}$ ceramics for engineering of novel, lightweight and mechanically stable medical implants. Further studies on deeper understanding of mechanical properties of $\mathrm{HA}$ coatings obtained on biomorphic nano-porous SiC ceramics using gas-detonation deposition, as well as cytotoxicity and in-vivo performance of such implants are planning.

Acknowledgments. This work was supported by the projects \#107/11-H and \#108/11-H national research program "Fundamental problems of nano-structured systems, nano-materials and nanotechnologies" and project \#3.5.3.4 of the national research program "Nanotechnology and nanomaterials".

\section{References}

1. Y.W.Gu, K.A.Khor, P.Cheang, Biomaterials, 24, 1603 (2003).

2. K.A.Khor, H.Li, P.Cheang, Biomaterials, 25, 1117 (2004).

3. J.M.Fernandez-Pradas, M.V.Garcia-Cuenca, L.Cleries et al., Appl. Surf. Sci., 195, 31 (2002).

4. K.A.Gross, C.C.Berndt, H.Herman, J.Biomed. Mater. Res., 39, 407(1998).

5. H.Li, K.A.Khor, P.Cheang, Mater.Sci.Eng.A, 293, 71 (2000).

6. C.G.Leeuwenburgha, J.G.C.Wolke, M.C.Siebers et al., Biomaterials, 27, 3368 (2006).

7. N.I.Klyui, V.P.Temchenko, A.P.Gryshkov et al., in: Proc. $8^{\text {th }}$ Int. Conf. on Nanoscience and Nanotechnologies - NN11, Thessaliniki, Greece (2011). 
8. Q.Zhou, S.Dong, Y.Ding et al., Ceram.Int., 35, 2161 (2009).

9. J.C.Margiotta, D.Zhang, D.C.Nagle, Int.J.Refract. Met.Hard Mater., 28, 191 (2010).

10. A.Centeno, V.G.Rocha, A.Borrell et al., Ceram. Int., 38, 2171 (2012).

11. V.O.Yukhymchuk, V.S.Kiselov, A.E.Belyaev et al., Phys. Stat. Solidi A, 208, 808 (2011).

12. V.S.Kiselov, P.M.Lytvyn, V.O.Yukhymchuk et al., J.Appl.Phys., 107, 093510 (2010).

13. V.M.Dzhagan, M.Ya.Valakh, A.A.Konchits et al., Function Materials, 16, 306 (2009)

14. Germany Patent $3,447,877$ (1986).

15. Germany Patent 3,441,079 (1986).

16. Germany Patent $3,440,870$ (1986).
17. N.I.Klyui, V.P.Temchenko, A.P.Gryshkov et al., Function Materials, 18, 1 (2011).

18. U.Posset, E.Loeckling, R.Thull et al., $J$. Biomed. Mater.Res., 40, 640 (1998).

19. H.Yu, H.Zhang, X.Wang et al., J.Phys.Chem. Sol., 68, 1863 (2007).

20. R.Ternane, M.Th.Cohen-Abad, G.Boulon et al., Sol. St. Ionics, 160, 183 (2003).

21. H.Li, B.S.Ng, K.A.Khor et al., Acta Materialia, 52, 445 (2004).

22. J.M.Fernandez-Pradas, L.Clerie, G.Sardin et al., Biomaterials, 23, 1989 (2002).

23. H.-L.Kim, Y.-S.Kim, D.-J.Kim et al., J.Korean Phys.Soc., 49, 2019 (2006).

24. J.M.Fernandez-Pradas, L.Clerie, G.Sardin et al., Biomaterials, 23, 1989 (2002).

\title{
Біо-SiC кераміка з гідроксиапатитовим покриттям, осадженим газо-детонаційним методом: альтернатива титановим медичним імплантам
}

\author{
М.І.Клюй, В.П.Темченко, О.П.Гришков, \\ В.А.Дубок, В.П.Кладько, А.В.Кучук, В.М.Джаган, \\ В.О.Юхимчук, В.С.Кисельов
}

Карбід-кремнієва (SiC) кераміка з осадженим біоактивним покриттям на основі гідроксиапатиту (ГАП) має потенціал з заміни традиційних титанових медичних імплантів. В роботі методами рентгеноструктурного аналізу, комбінаційного розсіювання світла та оптичної мікроскопії досліджено морфологію, структурні властивості та фазовий склад покриттів ГАП, осаджених на нанопористу біо-SiC кераміку з паралельною або перпендикулярною орієнтацією пор газо-детонаційним методом. Після 5 секунд осадження на покритті спостерігалися мікротріщини та відшаровування, в той час як рівномірне покриття утворилося внаслідок осадження протягом 10 секунд. Рентгеноструктурний аналіз покриття виявив збереження кристалічної структури вихідного порошку. За результатами комбінаційного розсіювання світла спостерігалося збільшення відношення площі кристалічного піку $\left(967 \mathrm{~cm}^{-1}\right)$ відносно аморфного (951 $\left.\mathrm{cm}^{-1}\right)$. Дане відношення було найбільшим для покриття, осадженого на $\mathrm{SiC}$ кераміку з паралельною орієнтацією пор, вказуючи, що структурні властивості SiC кераміки впливають на морфологію та структурну досконалість осаджених покриттів ГАП. 